\title{
The Ets Transcription Factor GABP Is Required for Postsynaptic Differentiation In Vivo
}

\author{
Alexandre Briguet and Markus A. Ruegg \\ Department of Pharmacology/Neurobiology, Biozentrum, University of Basel, CH-4056 Basel, Switzerland
}

\begin{abstract}
At chemical synapses, neurotransmitter receptors are concentrated in the postsynaptic membrane. During the development of the neuromuscular junction, motor neurons induce aggregation of acetylcholine receptors (AChRs) underneath the nerve terminal by the redistribution of existing AChRs and preferential transcription of the AChR subunit genes in subsynaptic myonuclei. Neural agrin, when expressed in nonsynaptic regions of muscle fibers in vivo, activates both mechanisms resulting in the assembly of a fully functional postsynaptic apparatus. Several lines of evidence indicate that synaptic transcription of $A C h R$ genes is primarily dependent on a promoter element called N-box. The Ets-related transcription factor growth-associated binding protein (GABP) binds to this motif and has thus been suggested to regulate synaptic gene expression. Here, we assessed the role of GABP in
\end{abstract}

synaptic gene expression and in the formation of postsynaptic specializations in vivo by perturbing its function during postsynaptic differentiation induced by neural agrin. We find that neural agrin-mediated activation of the AChR $\epsilon$ subunit promoter is abolished by the inhibition of GABP function. Importantly, the number of AChR aggregates formed in response to neural agrin was strongly reduced. Moreover, aggregates of acetylcholine esterase and utrophin, two additional components of the postsynaptic apparatus, were also reduced. Together, these results are the first direct in vivo evidence that GABP regulates synapse-specific gene expression at the neuromuscular junction and that GABP is required for the formation of a functional postsynaptic apparatus.

Key words: GABP; transcription; dominant-negative; neuromuscular junction; synapse; acetylcholine receptor
Chemical synapses are highly specialized subcellular structures destined for communication between cells in the nervous system. To warrant efficient signal transmission, neurotransmitter receptors are clustered underneath the nerve terminal. Motor neuroninduced differentiation of the postsynaptic apparatus, and in particular clustering of the acetylcholine receptors (AChRs), is based on at least two different mechanisms. First, existing molecules are reorganized to accumulate underneath the nerve terminal. Second, transcription of synaptic genes is restricted to the myonuclei underlying the presynaptic nerve terminal. The signals for activating both mechanisms are derived from motor neurons (Sanes and Lichtman, 1999). Recent evidence strongly suggests that certain splice variants of the large heparan sulfate proteoglycan agrin are sufficient to activate both mechanisms (for review, see Ruegg and Bixby, 1998). Clustering of existing molecules is mediated directly by the binding of neural agrin to a receptor complex combining the muscle-specific receptor tyrosine kinase (MuSK) (Glass et al., 1996). Alterations in gene transcription in turn are thought to be an indirect effect of agrin affecting activation of a second signaling system, including the neuregulins and their receptors, the erbB receptors (Fischbach and Rosen, 1997; Meier et al., 1998b; Rimer et al., 1998).

Expression of synaptic genes in the polynucleated muscle fiber changes during development. First, as myoblasts fuse, most of these genes are transcribed throughout the myofiber in a tissue-specific manner as part of the myogenic program driven by basic helix-loophelix (bHLH) transcription factors of the MyoD family (for review, see Edmondson and Olson, 1993). Upon innervation and initiation of electrical activity, transcription of synaptic genes is downregu-

\footnotetext{
Received March 6, 2000; revised May 1, 2000; accepted May 11, 2000.

This work was supported by the Swiss National Science Foundation Grant 3151013.97 and the Schweizerische Stiftung für die Erforschung der Muskelkrankheiten. We are grateful to Dr. H.-R. Brenner, who helped us in the initial stages of this work and granted us access to the cDNA injection setup. We thank Maya Enz for taking care of the rats. The AChR $\epsilon$-subunit reporter construct was a gift from Dr. Graham Jones, and the NLS-GFP construct was a gift from Dr. Said Hashemolhosseini. We also thank Dr. Gabriela Bezakowa and Dr. Thomas Meier for critical reading of this manuscript. Correspondence should be addressed to Dr. Markus A. Ruegg, Department of Pharmacology/Neurobiology, Biozentrum, University of Basel, Klingelbergstrasse 70, CH-4056 Basel, Switzerland. E-mail: markus-a.ruegg@unibas.ch.

Copyright (c) 2000 Society for Neuroscience $0270-6474 / 00 / 205989-08 \$ 15.00 / 0$
}

lated throughout the myofiber (Eftimie et al., 1991; Witzemann and Sakmann, 1991; Buonanno et al., 1992; Huang et al., 1992; Neville and Schmidt, 1992; Huang et al., 1993; Mendelzon et al., 1994; Merlie et al., 1994). At synaptic sites, expression of many synaptic genes, including AChR $\alpha, \beta, \delta$, and $\gamma$ subunits (Goldman and Staple, 1989; Brenner et al., 1990), rapsyn, N-CAM (Moscoso et al., 1995), and MuSK (Bowen et al., 1998), is maintained. Moreover, transcription of the AChR $\epsilon$ subunit (Brenner et al., 1990) and expression of the laminin $\beta 2$ chain (Patton et al., 1997) are selectively initiated upon innervation. Persistent transcription of synaptic genes in subsynaptic myonuclei implies the existence of mechanisms that are able to locally activate gene transcription in electrically active myofibers.

Activation of gene transcription by bHLH transcription factors requires the E-box promoter element (Weintraub, 1993; Duclert and Changeux, 1995). However, synapse-specific gene expression is independent of this motif (Duclert et al., 1993; Chu et al., 1995). Efforts to map the motif necessary for the synaptic gene expression have led to the identification of the N-box (Koike et al., 1995). In cultured muscle cells, this N-box motif (CCGGAA) is necessary for neuregulin-induced upregulation of the genes encoding $\mathrm{AChR} \delta$ and $\epsilon$ subunits (Duclert et al., 1996), utrophin (Gramolini et al., 1999; Khurana et al., 1999), and acetylcholine esterase (AChE) (Chan et al., 1999). The transcription factor that binds to this motif is the Ets-related growth-associated binding protein (GABP) (Fromm and Burden, 1998; Schaeffer et al., 1998). Cotransfection of dominant-negative mutants of GABP inhibits neuregulininduced expression of reporter constructs of the AChR $\epsilon$ and the $\mathrm{AChR} \delta$ promoter in cultured muscle cells (Schaeffer et al., 1998). GABP is an ubiquitously expressed transcription factor composed of two subunits, GABP $\alpha$ and GABP $\beta$ (LaMarco et al., 1991). The GABP $\alpha$ subunit, a member of the Ets family of transcription factors, mediates DNA binding (Thompson et al., 1991). The GABP $\beta$ subunit has no intrinsic DNA-binding property but has an $\mathrm{N}$-terminal domain that mediates highly specific interaction with GABP $\alpha$ (Thompson et al., 1991; Brown and McKnight, 1992; Batchelor et al., 1998). In addition, the C-terminal part of GABP $\beta$ is required for GABP-induced transcriptional activation (Sawa et al., 1996). Because GABP binds to the N-box and the N-box is involved in the synaptic expression of the AChR $\epsilon$ and $\delta$ subunits, 
utrophin, and the AChE gene, it has been proposed that GABP may serve as the transcriptional activator for synaptic gene expression. To test this hypothesis, it is necessary to study the role of GABP during postsynaptic differentiation in vivo. This is particularly important because muscle fibers are electrically active and electrical activity strongly influences transcription of synaptic genes. Here, we induce postsynaptic differentiation in innervated muscle fibers by ectopic expression of neural agrin and investigate the function of GABP during this process.

\section{MATERIALS AND METHODS}

Constructs. The expression construct encoding full-length chick agrin cAgrin $_{7 \mathrm{~A} 4 \mathrm{~B} 8}$ has been described previously (Denzer et al., 1995). The NLSGFP construct encoding green fluorescent protein (GFP) with a nuclear localization sequence (NLS) has been described by Jones et al. (1999). The GABP $\alpha$ and GABP $\beta$ cDNAs were amplified by PCR from a C2C12 mouse muscle cells cDNA library using the following primers: $\operatorname{SGABP} \alpha, 5^{\prime}$ GGAATTCGTCTTCAACCATGACTA 3'; asGABP $\alpha$, 5' TGCATGCATGGTCCTAGGTCTCAAATC $3^{\prime}$; sGABP $\beta$, 5' GGAATTCGAAGCTTTTCCAGATGT $3^{\prime}$; and asGABP $\beta, 5^{\prime}$ TGCATGCATGTTCATGGCAGCTAAAC $3^{\prime}$. The PCR products were cloned into pcDNA1 (Invitrogen, Carlsbad, CA) opened with EcoRI and EcoRV. The dominantnegative construct of GABP $\beta\left(\mathrm{GABP} \beta^{\mathrm{DN}}\right)$ was generated by PCR using primers $5^{\prime}$ GGAATTCGAAGCTTTTCCAGATGT $3^{\prime}$ (sGABP $\beta$ ) and $5^{\prime}$ CTATCATTCTGCACATTCCACCC $3^{\prime}$ (asGABP $\beta^{\mathrm{DN}}$ ) and cloning the PCR product into pcDNA1 opened with EcoRI and EcoRV. The GABP $\alpha$ myc construct was made by PCR using primers $5^{\prime}$ GGAATTCGTCTTCAACCATGACTA $3^{\prime}(\operatorname{sGABP} \alpha)$ and $5^{\prime}$ GCTCTAGAAATCTCTTTGTCTGCCTGT 3' (asGABP $\alpha X b a \mathrm{I})$ and cloning the PCR product into the EcoRI and $X b a$ I sites of p_myc, a pcDNA1-based vector that includes five copies of the myc epitope (Meier et al., 1998a). The NLS-LacF plasmid was constructed by cloning a SalI-SphI fragment of the pnlacF plasmid (Lanford et al., 1988) into pcDNA1 opened with XhoI and SphI. The AChR $\epsilon$ subunit reporter construct has been described previously (Jones et al., 1996). Plasmids were purified using a Nucleobond AX 500 kit (Macherey-Nagel, Düren, Germany). PCR and DNA manipulations for cloning were performed according to standard protocols. All constructs were verified by DNA sequencing.

Transfection of GABP constructs in COS-7 cells. COS-7 cells (Gluzman, 1981) were transiently transfected with GABP expression constructs using the Fugene 6 transfection reagent (Roche Diagnostics, Rotkreuz, Switzerland). The cells were then processed for intracellular anti-myc staining as follows. After washing with PBS, the cells were fixed for $30 \mathrm{~min}$ at room temperature with $4 \%$ paraformaldehyde and $11 \%$ sucrose in $0.1 \mathrm{M}$ potassium phosphate buffer, $\mathrm{pH}$ 7.2. After rinsing with PBS and $20 \mathrm{~mm}$ glycine in PBS, cells were permeabilized with PBS containing $0.1 \%$ saponin (PBSS) and 10\% normal goat serum (NGS) for $20 \mathrm{~min}$ at room temperature. The cells were then incubated with the anti-myc monoclonal antibody 9E10 (Evan et al., 1985) diluted to $1 \mu \mathrm{g} / \mathrm{ml}$ in PBSS and 10\% NGS. After four washes with PBSS, cells were incubated with a Cy3-conjugated goat anti-mouse IgG (Molecular Probes, Eugene, OR), diluted to $0.5 \mu \mathrm{g} / \mathrm{ml}$ in PBSS and $10 \%$ NGS for $1 \mathrm{hr}$ at room temperature. After washing, cultures were mounted on glass coverslips with citifluor (Plano) and examined with a microscope equipped with epifluorescence (Leica, Nussloch, Germany).

Injection of cDNA into muscle fibers. The expression plasmids were injected into single muscle fibers of young adult rats $(120 \mathrm{gm})$ as described previously (Jones et al., 1997; Meier et al., 1997). In the AChR $\epsilon$ subunit reporter experiment, the NLS-LacF construct and the AChR $\epsilon$ reporter were injected at $100 \mathrm{ng} / \mu \mathrm{l}$, the agrin construct was injected at $4 \mathrm{ng} / \mu \mathrm{l}$, and the GABP $\beta^{\text {DN }}$ construct was injected at $50 \mathrm{ng} / \mu \mathrm{l}$. The total amount of plasmid injected was kept constant in each experiment by complementing with pcDNA1 vector (Invitrogen). Two weeks after injection, the soleus muscle was taken out and frozen in liquid nitrogen, the injected region was homogenized in $500 \mu \mathrm{l}$ reporter lysis buffer (Promega, Madison, WI), an luciferase activity was measured using the luciferase assay system (Promega). Reporter gene activity was normalized to the $\beta$-galactosidase activity derived from the coinjected NLS-LacF plasmid. In all remaining experiments, the agrin construct was injected at $4 \mathrm{ng} / \mu \mathrm{l}$, the NLS-GFP construct at $50 \mathrm{ng} / \mu \mathrm{l}$, and the NLS-LacF construct or the GABP $\beta^{\text {DN }}$ construct at $50 \mathrm{ng} / \mu \mathrm{l}$.

Immunohistochemistry and antibodies. To visualize AChRs, the entire soleus muscle was bathed for $1 \mathrm{hr}$ at $4^{\circ} \mathrm{C}$ in L-15 medium (Life Technologies, Gaithersburg, MD) containing $1 \mu \mathrm{g} / \mathrm{ml}$ alexa_ $\alpha$-bungarotoxin or rhodamine_ $\alpha$-bungarotoxin (Molecular Probes). For the utrophin staining, $14-\mu \mathrm{m}$-thick frozen cross-sections were first fixed with $1 \%$ paraformaldehyde for $5 \mathrm{~min}$, washed briefly with PBS, and preincubated for $15 \mathrm{~min}$ in PBS supplemented with 5\% horse serum, $1 \%$ bovine serum albumin, and $0.01 \%$ Triton $\mathrm{X}-100$. Sections were incubated overnight at $4^{\circ} \mathrm{C}$ with the anti-utrophin monoclonal antibody NCL-DRP2 (Novocastra, Newcastle upon Tyne, UK) diluted 1:200 in PBS, 5\% horse serum, $1 \%$ bovine serum albumin, and $0.01 \%$ Triton X-100. For detection, Cy3-conjugated goat anti-mouse IgG was used. Acetylcholinesterase was detected on crosssections according to Pestronk and Drachman (1978). Whole-mount preparations were examined with a confocal microscope (Leica) and crosssections with a microscope equipped with epifluorescence (Leica).
A
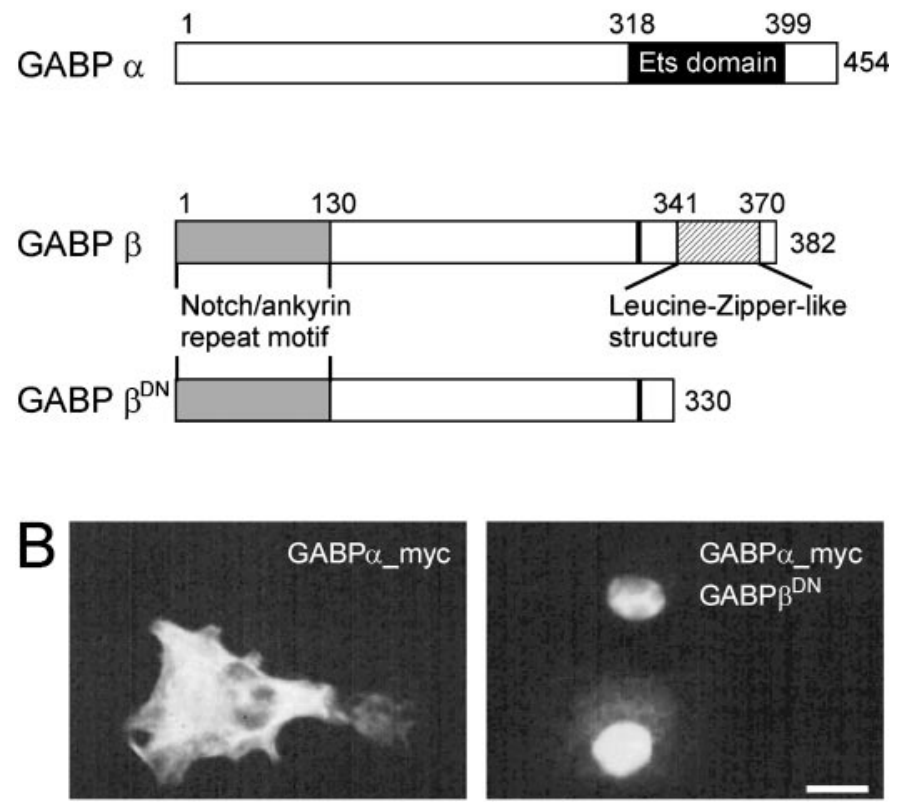

Figure 1. Structure of GABP $\alpha$ and $\beta$ subunits and expression in COS-7 cells. $A$, Scheme of the $\alpha$ and $\beta$ subunits of GABP and the dominantnegative construct. The black region (aa 318-399) indicates the Ets-related DNA binding domain of GABP $\alpha$. The region between aa 318-454 is necessary for the binding to GABP $\beta$. In GABP $\beta$, the gray region (aa 1-130) represents four tandem repeats of a Notch/ankyrin motif required for heterodimerization with GABP $\alpha$. The black bar indicates the approximate location of a nuclear localization sequence. The hatched region (aa 341$370)$ represents the transactivation domain. In the dominant-negative mutant $\left(\mathrm{GABP} \beta^{\mathrm{DN}}\right)$ used in this study, the last 52 amino acids of $\mathrm{GABP} \beta$ were deleted. $B$, Intracellular anti-myc staining of COS cells transfected with myc-tagged GABP $\alpha$ constructs. GABP $\alpha$ is localized in the cytoplasm (left). Upon cotransfection with GABP $\beta^{\text {DN }}$, GABP $\alpha$ accumulates in the cell nucleus (right). This indicates that the truncated $\mathrm{GABP} \beta^{\mathrm{DN}}$ protein dimerizes with the $\alpha$ subunit and translocates into the cell nucleus. Scale bar, $20 \mu \mathrm{m}$

Quantification. Quantification of AChR clustering is presented as the number of fibers that are AChR cluster-positive on each consecutive cross-section made across entire injection sites. Cross-sections were preferred to whole-mount preparations for the evaluation because they allow to attribute clusters to individual fibers unequivocally. A muscle fiber was defined cluster-positive when a clear and sharp rhodamine_ $\alpha$-bungarotoxin staining was detected on its membrane. A given muscle fiber was defined cluster-positive independently of the size or of the number of the AChR clusters.

\section{RESULTS}

\section{A dominant-negative mutant of GABP $\beta$ abrogates activation of the AChR $\epsilon$ subunit promoter in vivo}

Transcriptional activation of genes by GABP requires heterodimerization of $\mathrm{GABP} \alpha$ and $\mathrm{GABP} \beta$. Whereas the $\alpha$ subunit contains the DNA-binding domain (Fig. $1 A$, Ets domain), GABP $\beta$ provides the signals for nuclear localization and transactivation of gene transcription. The $\mathrm{N}$-terminal region of the $\beta$ subunit contains Notch/ankyrin-like repeats that mediate heterodimerization. To generate a dominant-negative mutant of GABP $\left(\mathrm{GABP} \beta^{\mathrm{DN}}\right)$, we deleted the 52 most $\mathrm{C}$-terminal amino acids (aa) of the $\beta$ subunit. This region contains a leucine-zipper-like structure that is necessary for transcriptional activation and for homodimerization (Fig. $1 A)$. A similar deletion construct has been shown to act as a dominant-negative for GABP-mediated transcription in cultured chick muscle cells (Schaeffer et al., 1998). To test whether $\operatorname{GABP} \beta^{\mathrm{DN}}$ still dimerizes with the GABP $\alpha$ subunit, which is requisite for its acting as a dominant-negative mutant, we transfected COS cells with GABP $\beta^{\mathrm{DN}}$ and a myc-tagged GABP $\alpha$ construct. Whereas GABP $\alpha$-myc, when transfected alone, was localized in the cytoplasm (Fig. $1 B$, left), most of the $\alpha$ subunit was 

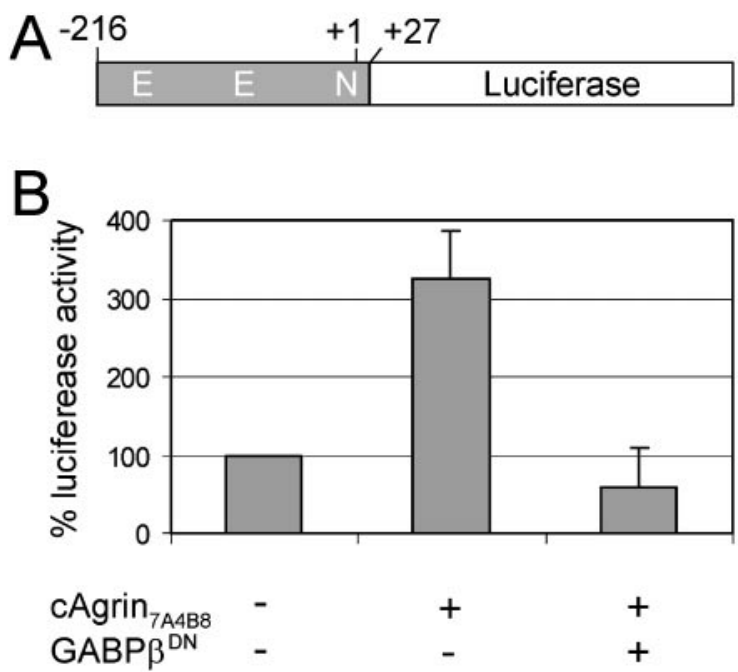

Figure 2. Agrin induces the expression of an $\mathrm{AChR} \epsilon$ subunit reporter construct via a GABP-dependent mechanism in vivo. $A$, Diagram of the $\mathrm{AChR} \epsilon$ subunit reporter construct used in this study. A fragment of the $\epsilon$ subunit gene ( gray) extending 216 bp upstream from the transcription start site drives the expression of a luciferase gene. This fragment contains two E-boxes $(E)$, putative binding sites for basic helix-loop-helix myogenic factors, and one $\mathrm{N}$-box $(N)$. $B$, In each individual experiment, luciferase activity of the $\mathrm{AChR} \epsilon$ reporter construct injected alone was set as $100 \%$ (first column). Coinjection of expression constructs encoding full-length

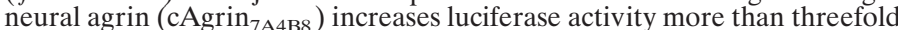
(second column; $p<0.01$ ). This increase is abolished by expression of the dominant-negative mutant of GABP $\beta$ (third column; $p<0.01$ ). Data represent mean \pm SDs of three independent injections (3 injected rats). Note that, in each individual injection, luciferase activity was normalized to the $\beta$-galactosidase activity derived from the coinjected NLS-LacF construct. The effect of neural agrin and GABP $\beta^{\mathrm{DN}}$ is specific for the AChR promoter because a muscle creatine kinase promoter construct was not affected by either condition (reporter alone, $100 \%$; reporter plus cAgrin $_{7 \mathrm{~A} 4 \mathrm{~B} 8}, 88.3 \%$; reporter plus cAgrin ${ }_{7 \mathrm{~A} 4 \mathrm{~B} 8}$ plus GABP $\beta^{\mathrm{DN}}, 87.2 \%$ ).

localized in the cell nucleus when $\mathrm{GABP} \beta^{\mathrm{DN}}$ was cotransfected (Fig. $1 B$, right). Thus, GABP $\beta^{\mathrm{DN}}$ oligomerizes with $\mathrm{GABP} \alpha$ and translocates the protein complex into the cell nucleus.

It has been demonstrated previously that expression of neural agrin in extrasynaptic regions of muscle fibers induces the formation of ectopic postsynaptic-like apparatus with mature functional properties, including upregulation of AChR $\epsilon$ mRNA (Cohen et al., 1997; Jones et al., 1997; Meier et al., 1997; Rimer et al., 1997). Thus, this model system is suitable for assessing the function of candidate genes in the development of postsynaptic specializations in vivo. In particular, it allows the study of mechanisms locally activating the transcription of synaptic genes in innervated muscle fibers. We therefore used this paradigm to determine whether GABP is responsible for the upregulation of the $\mathrm{AChR} \epsilon$ subunit during postsynaptic differentiation. To this aim, we tested whether $\mathrm{GABP} \beta^{\mathrm{DN}}$ was able to block induction of the AChR $\epsilon$ subunit expression using a reporter construct in which a promoter fragment of the mouse AChR $\epsilon$ subunit gene drives the expression of a luciferase gene (Fig. 2A). This reporter construct is activated by substrate-bound agrin and by neuregulin in a mouse muscle cell line (Jones et al., 1996). The $\epsilon$ subunit reporter construct was injected into extrasynaptic regions of 30 individual innervated myofibers of the rat soleus muscle together with a construct in which $\beta$-galactosidase is expressed under the control of the cytomegalovirus promoter (NLS-LacF). Luciferase activity was measured 2 weeks later in homogenates of the injected muscles and normalized to the $\beta$-galactosidase activity derived from the NLSLacF construct. The normalized luciferase activity measured in muscles injected with the AChR $\epsilon$ subunit reporter alone was set as $100 \%$ (Fig. 2B, first column). Coinjection of an expression plasmid encoding full-length neural agrin $\left(\mathrm{cAgrin}_{7 \mathrm{~A} 4 \mathrm{~B} 8}\right)$ (Denzer et al., $1995)$ increased the expression of the reporter more than threefold (Fig. $2 B$, second column). Upon coinjection of GABP $\beta^{\mathrm{DN}}$, lucif- erase activity dropped to the level of the noninduced situation (Fig. $2 B$, third column). These results show that upregulation of the $\mathrm{AChR} \epsilon$ gene by neural agrin in vivo requires a functional GABP $\alpha / \beta$ complex, and they suggest that the basal activity of the AChR $\epsilon$ promoter does not depend on GABP. Indeed, an AChR $\epsilon$ promoter construct in which the N-box is mutated shows the same basal activity as the wild-type promoter in innervated muscle fibers (A. Briguet, A. Abicht, M. A. Ruegg, and H. Lochmüller, unpublished observation). Moreover, GABP-dependent induction of gene transcription by neural agrin is specific for the AChR $\epsilon$ promoter because we did not observe any alterations in the level of expression of a luciferase reporter driven by a $1.3 \mathrm{~kb}$ fragment of the muscle creatine kinase (MCK) promoter (Jaynes et al., 1986). In these experiments, normalized expression of the MCK reporter was $100 \%$ (reporter alone), $88 \%$ (reporter plus cAgrin 7A4B8 $_{4}$ ), and $87 \%$ (reporter plus cAgrin $7 \mathrm{~A} 4 \mathrm{~B} 8$ plus $\mathrm{GABP} \beta^{\mathrm{DN}}$ ).

\section{GABP $\beta^{\mathrm{DN}}$ prevents the induction of ectopic postsynaptic structures in innervated muscle fibers}

To address the question whether a functional $\operatorname{GABP} \alpha / \beta$ complex is required for the formation of agrin-induced postsynaptic structures in vivo, we examined next the influence of the dominant-negative construct of GABP $\beta$ on the induction of ectopic AChR clusters. In control experiments, cDNA encoding full-length neural chick agrin $\left(\mathrm{cAgrin}_{7 \mathrm{~A} 4 \mathrm{~B} 8}\right)$ was injected together with an expression construct for nuclear-targeted $\beta$-galactosidase (NLS-LacF) to adjust the amount of protein synthesized by the injected fiber. To identify the injected muscle fibers, a third construct encoding nuclear-targeted GFP (NLS-GFP) was always included. Two weeks after injection, ectopic postsynaptic specializations were visualized using rhodamine-labeled $\alpha$-bungarotoxin $\left(\begin{array}{ll}R h & \alpha b g t\end{array}\right)$. As shown in Figure $3 A$, control-injected muscle fibers expressed many AChR clusters. Myonuclei often aggregated underneath such AChR clusters (arrowheads), indicating that these ectopic postsynaptic structures show also signs of synaptic maturation (Jones et al., 1997). In muscle fibers injected with the dominant-negative GABP $\beta$ mutant, no or only a few AChR clusters were associated with the injected fibers (Fig. $3 B, G A B P \beta^{D N}$ ). Under these and control conditions, neural agrin is able to diff use to adjacent fibers; therefore, we often observed AChR clusters in nearby, noninjected muscle fibers (Fig. 3, asterisks).

To quantify the effect of GABP $\beta^{\mathrm{DN}}$ on $\mathrm{AChR}$ clustering, we made consecutive cross-sections through the entire injection sites and determined the number of GFP-positive fibers $(G F P)$, the number of GFP-positive fibers that expressed AChR clusters $(C /$ $G F P$ ) and the total number of fibers with AChR clusters (Ctot), on individual sections (Fig. 4A,B). Cross-sections were used for this quantification because only this method allows to assign AChR clusters unequivocally to individual injected or neighboring, noninjected muscle fibers (see Fig. $4 C$ as an example). Figure $4, A$ and $B$, shows the counts for one muscle from control (Fig. 4A) and GABP $\beta^{\text {DN }}$-injected (Fig. $4 B$ ) animals. In the examples shown in Figure 4, $A$ and $B$, the injection sites extended over 50 consecutive, $14-\mu \mathrm{m}$-thick cross-sections. Although the number of GFP-positive fibers was approximately the same in both cases (15-17 vs 16-19), the total number of fibers with AChR clusters and the number of GFP-positive muscle fibers with AChR clusters clearly decreased in muscle injected with the dominant-negative GABP $\beta$ construct. To compare the proportion of injected fibers that developed AChR clusters in the control injection versus the GABP $\beta^{\mathrm{DN}}$ injection, we summed the numbers obtained on individual cross-sections throughout the injection sites and set the number of injected fibers (GFP-positive) as $100 \%$. The counts obtained from three control and three GABP $\beta^{\mathrm{DN}}$ injections are listed in Table 1 . Whereas in the controls $29.6 \pm 3.4 \%$ of the injected muscle fibers developed AChR clusters, in the GABP $\beta^{\text {DN }}$ injections only $12.3 \pm 1.6 \%$ of the injected muscle fibers developed AChR clusters. The number of adjacent, noninjected muscle fibers that formed AChR clusters was not significantly different in the $\mathrm{GABP} \beta^{\mathrm{DN}}$-injected compared with the control-injected muscles. This shows that the capability of 

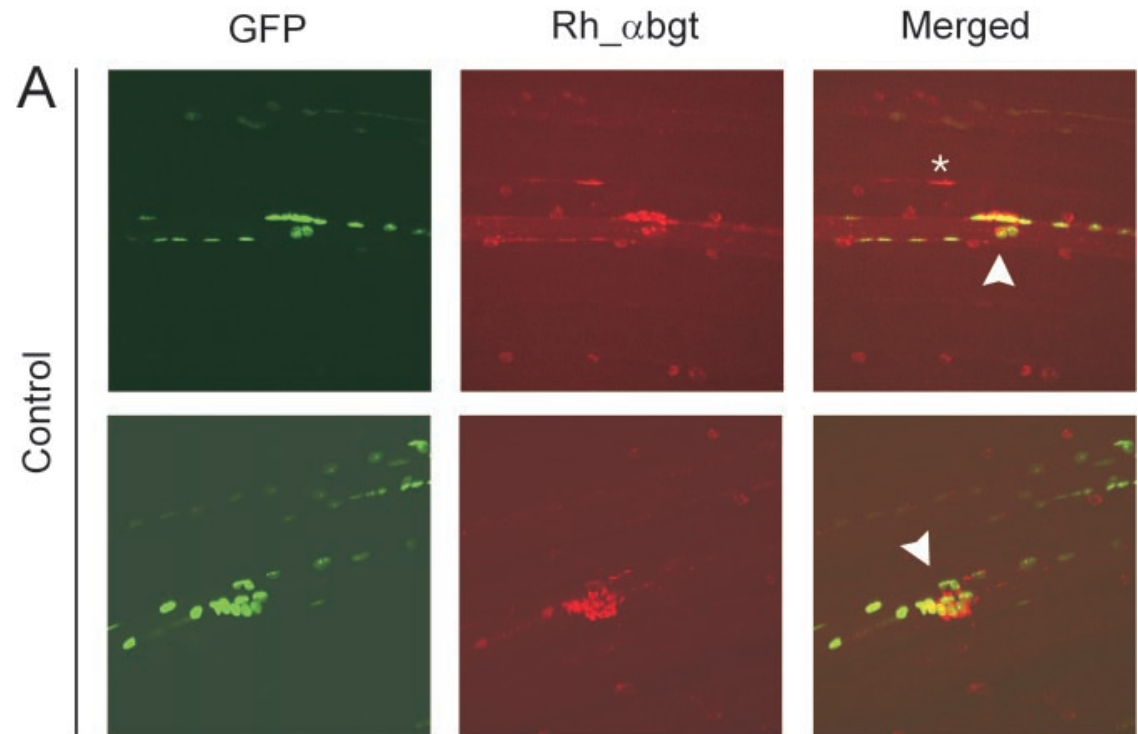

Figure 3. Whole-mount confocal views of cDNAinjected muscle fibers. $A$, Two representative examples of control muscle fibers that were injected with a construct encoding NLS-LacZ, full-length neural agrin and NLS-GFP. The injected fibers are identified by the presence of GFP-positive nuclei $(G F P)$. AChR clusters are stained with rhodamine_ $\alpha$-bungarotoxin $\left(R h \_\alpha-b g t\right)$. Many injected fibers form AChR clusters in response to neural agrin and aggregates of GFP-positive nuclei are found underneath the AChR clusters (arrowheads). B, Two representative examples of muscle fibers expressing the dominant-negative mutant of GABP $\beta$, neural agrin, and NLS-GFP. GFP-positive muscle fibers are devoid of AChR clusters and aggregates of myonuclei. Note that, in neighboring noninjected muscle fibers, AChR aggregates were formed (asterisks). The fluorescence spots that appear in both channels are unspecific staining. Scale bar, $50 \mu \mathrm{m}$.
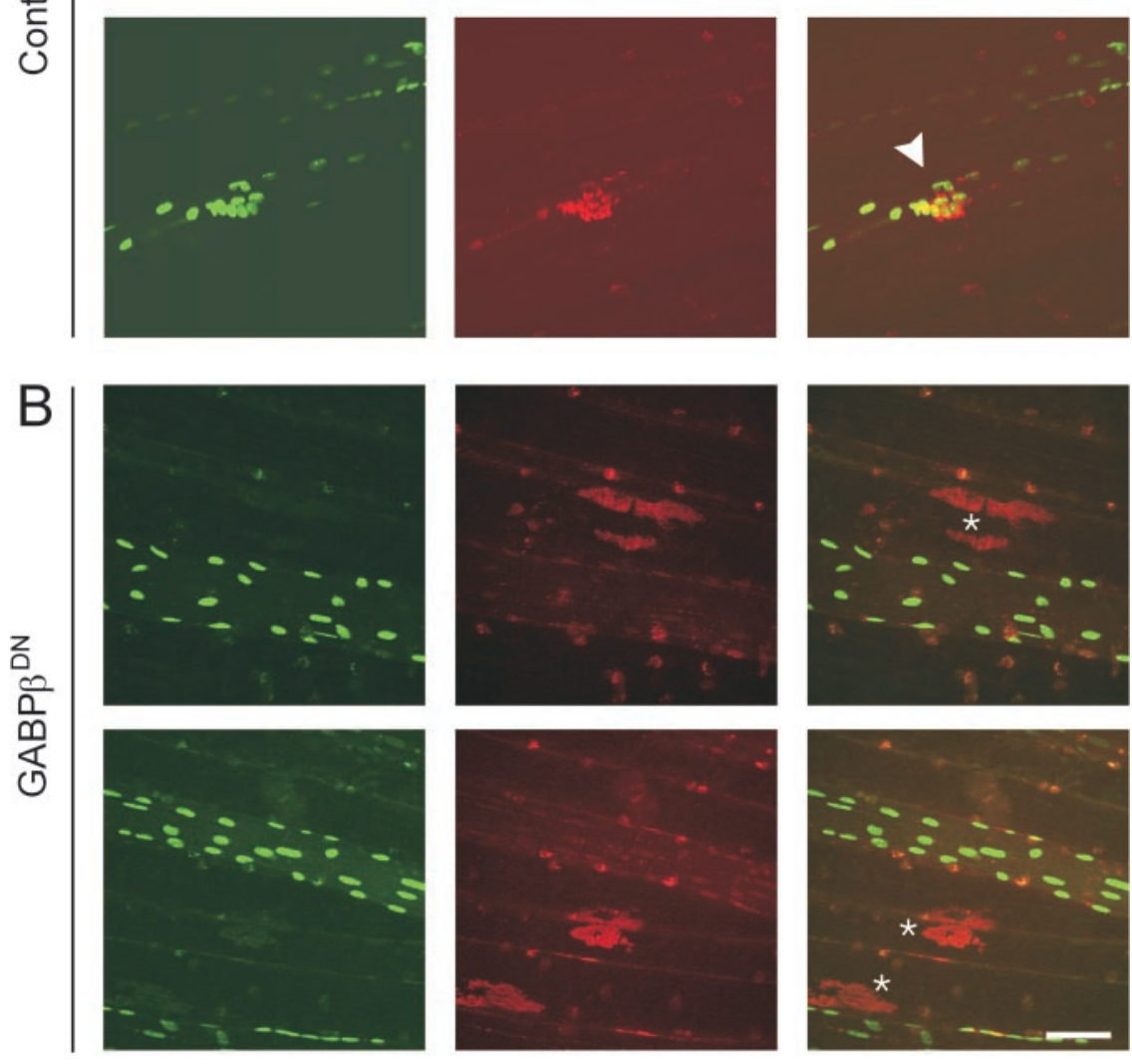

neural agrin to induce $\mathrm{AChR}$ clustering remained unaffected in the noninjected muscle fibers. In summary, these experiments show that GABP function is required to form clusters of AChRs in innervated muscle fibers.

\section{Utrophin and AChE aggregates are also reduced in muscle fibers that express GABP $\beta^{\text {DN }}$}

The previous experiments suggest that GABP-mediated transcriptional activation is required for agrin-induced clustering of AChRs and that the $\mathrm{AChR} \epsilon$ subunit is one postsynaptic molecule locally upregulated by GABP during postsynaptic differentiation. To determine whether clustering of other components of the postsynaptic apparatus also depends on GABP, we analyzed the distribution of two other synaptic molecules: AChE and utrophin. AChE is an enzyme concentrated in the synaptic basal lamina of the muscle fibers. Whereas the association of other synaptic proteins with the postsynaptic apparatus requires the continuous presence of the AChRs, the localization of AChE to the neuromuscular junction (NMJ) persists even if AChRs are lost (Missias et al., 1997). Moreover, in rapsyn-deficient mice, AChE aggregates form underneath the nerve terminal, although AChR clusters fail to form in the postsynaptic membrane (Gautam et al., 1995). AChE could therefore have formed aggregates devoid of AChRs in myofibers injected with $\mathrm{GABP} \beta^{\mathrm{DN}}$. Utrophin is an intracellular protein tightly associated with AChRs at the NMJ. However, mice deficient in utrophin still develop a postsynaptic apparatus, including aggregates of AChRs (Grady et al., 1997). Therefore, GABP $\beta^{\mathrm{DN}}$ - mediated perturbation of synaptic gene transcription may have led to the formation of $\mathrm{AChR}$ clusters devoid of utrophin. As shown in Figure 5, the number of utrophin and $\mathrm{AChE}$ aggregates was also decreased in the GABP $\beta^{\mathrm{DN}}$ injection. Both utrophin (Fig. $5 A, B$ ) and AChE (Fig. $5 C$ ) were always associated with AChR clusters in control-injected and GABP $\beta^{\mathrm{DN}}$-injected muscle fibers. Thus, interfering with GABP function inhibits the formation of the entire postsynaptic apparatus but does not affect the molecular composition of the postsynaptic structures per se.

\section{DISCUSSION}

Two distinct mechanisms contribute to the formation and maintenance of postsynaptic specializations at the neuromuscular junction. First, molecules expressed by noninnervated muscle fibers are clustered underneath the motor nerve terminal and assemble into an intricate network of proteins. Second, synaptic genes are preferentially transcribed in subsynaptic myonuclei. Studies on cultured myotubes suggested that neural agrin is responsible for the aggregation of existing molecules (Wallace, 1988), whereas ARIA, a member of the neuregulins, increases AChR synthesis (Fischbach and Rosen, 1997). However, studies in vivo have provided strong evidence that both mechanisms are triggered by the sole action of neural agrin (Cohen et al., 1997; Jones et al., 1997; Meier et al., 1997; Rimer et al., 1997). The requirement of neural agrin for activating gene transcription is supported by the finding that mice deficient of agrin or its signaling receptor MuSK do not express 


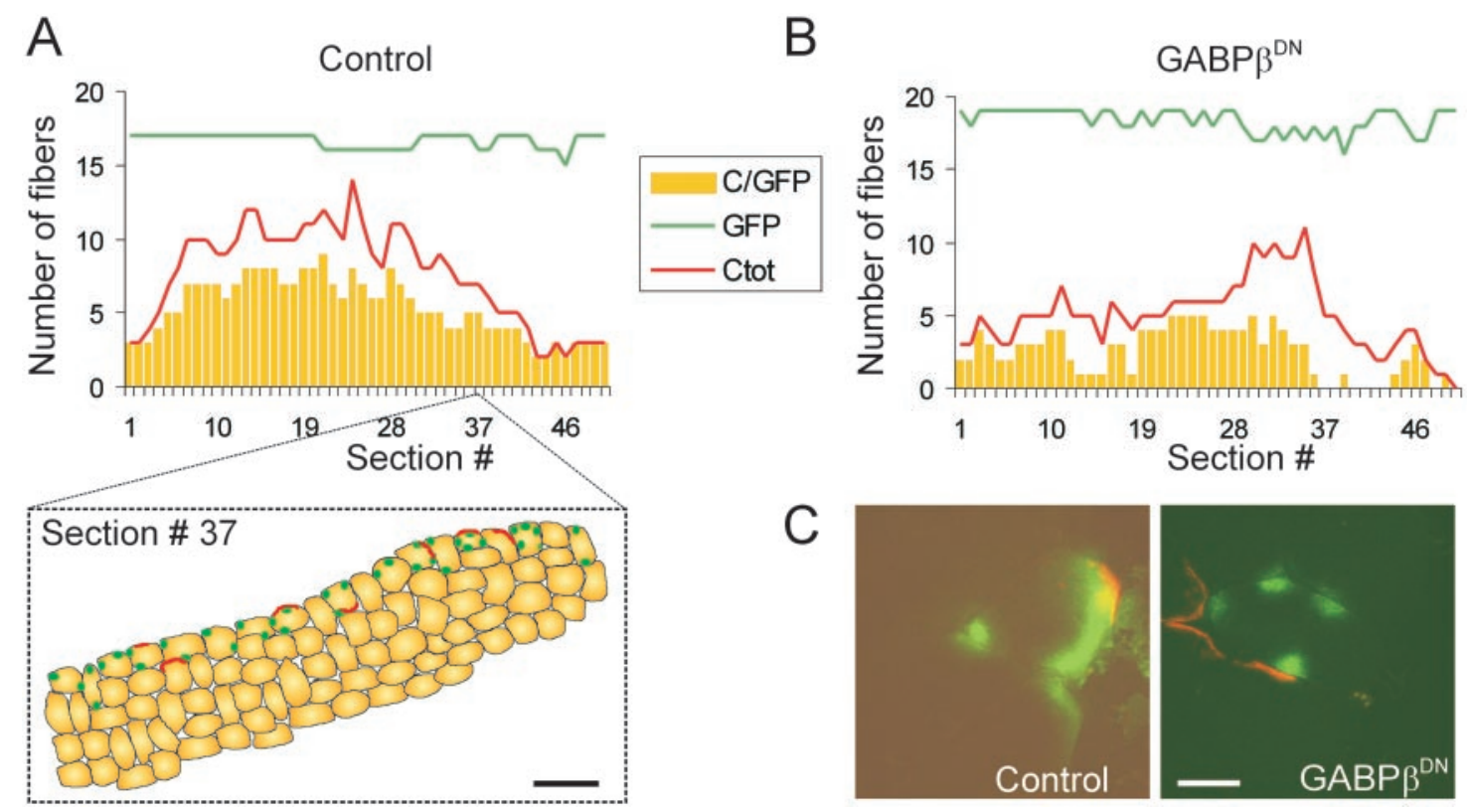

Figure 4. Quantification of the influence of GABP $\beta^{\mathrm{DN}}$ on AChR clustering. $A, B$, Quantitative assessment of the effect of GABP $\beta^{\mathrm{DN}}$ in one individual cDNA injection experiment. Histograms of the number of GFP-positive fibers that formed AChR clusters (C/GFP; yellow bars), GFP-positive muscle fibers (GFP; green line), and the total number of fibers that formed AChR aggregates (Ctot; red line) counted on 14- $\mu \mathrm{m}$-thick consecutive cross-sections through the entire injection sites. For illustration, a camera lucida drawing of section 37 (\#37) is shown in $A$. In this particular section, 16 GFP-positive muscle fibers $(G F P)$ were counted, and seven fibers formed AChR clusters $(C t o t)$. Five of these fibers were also GFP-positive $(C / G F P)$. Scale bar, $50 \mu \mathrm{m}$. $C$, Confocal views of cross-sections of a control-injected muscle fiber (left) and a GABP $\beta^{\mathrm{DN}}$-injected muscle fiber (right). Injected fibers are identified by the expression of GFP (green). In the control, AChR clusters (red) are associated with myofibers containing GFP-positive nuclei. In contrast, in the GABP $\beta^{\mathrm{DN}}$-injected muscle, AChR clusters are found in adjacent, GFP-negative myofibers. Scale bar, $20 \mu \mathrm{m}$.

Table 1. Quantification of AChR clustering in three control and GABP $\beta^{\text {DN }}$ injection experiments

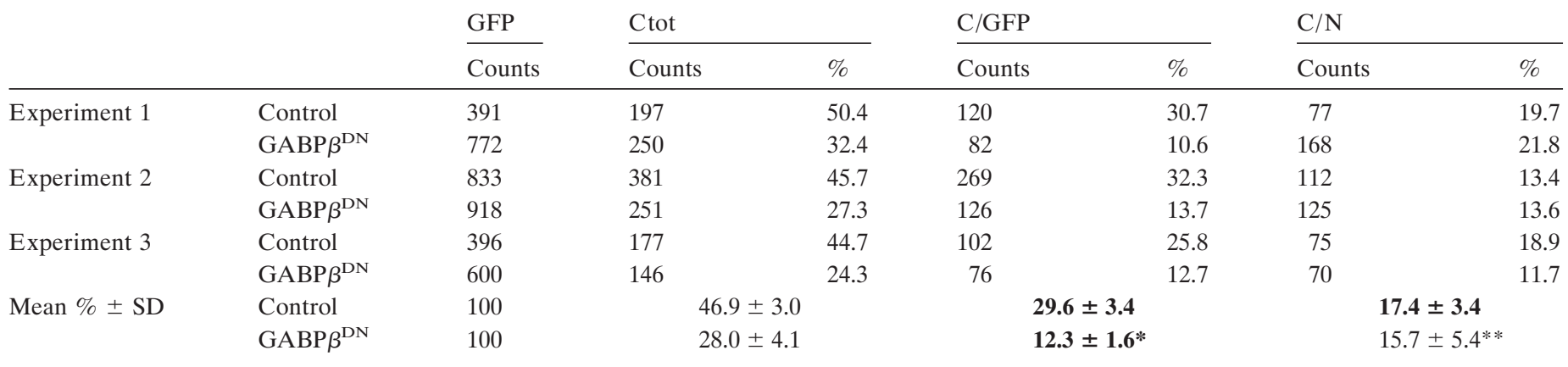

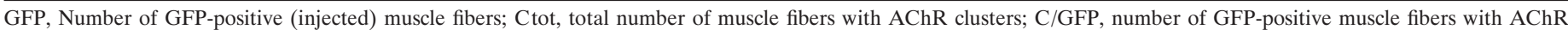

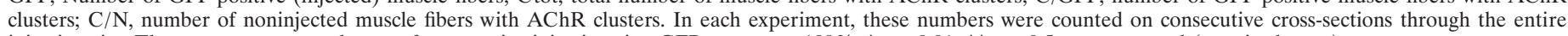
injection site. The counts represent the sum for an entire injection site. GFP was set as $100 \%$. ${ }^{*} p<0.01$; * $p>0.5$ versus control (unpaired $t$ test).

AChR subunits in distinct myonuclei (DeChiara et al., 1996; Gautam et al., 1996). Several lines of evidence strongly suggest that the function of neural agrin in regulating gene transcription at the NMJ involves the neuregulins and their cognate receptors, the erbB receptors (Meier et al., 1998b). Indeed, mice in which one allele of the neuregulin-1 gene has been deleted are myasthenic as a result from a decrease in postsynaptic AChR density (Sandrock et al., 1997). In addition, the neuregulin-induced increase in AChR subunit expression is inhibited by erbB kinase inhibitor in cultured muscle cells ( $\mathrm{Si}$ and Mei, 1999). These data strongly suggest a role of neuregulin/erbB-signaling in the formation and maintenance of postsynaptic specializations.

The evidence that the Ets-related transcription factor GABP is a downstream target of agrin and of neuregulin is so far solely based on experiments using cultured muscle cells. Moreover, Sapru et al. (1998) have shown that overexpression of Ets-2, another Ets transcription factor expressed in muscle, is able to activate transcription of an AChR $\epsilon$ reporter construct in cultured muscle cells. To investigate the involvement of GABP in regulating gene transcription at the NMJ in vivo, we have used the paradigm of injecting
cDNA constructs encoding neural agrin into extrasynaptic regions of innervated muscle fibers, an experimental approach that reiterates the events occurring in the motor neuron-induced development of postsynaptic structures. We found that a dominantnegative mutant of GABP $\beta$ blocks (1) the upregulation by agrin of the AChR $\epsilon$ subunit gene and (2) the formation of postsynaptic structures. Thus, our data are the first in vivo evidence that GABP is required for the local activation of gene transcription in subsynaptic myonuclei. These data, together with the strong evidence that the N-box motif is important for synaptic expression of the AChR $\epsilon$ and $\delta$ subunits (Koike et al., 1995; Duclert et al., 1996), utrophin (Gramolini et al., 1999; Khurana et al., 1999), and AChE (Chan et al., 1999), make GABP a key transcription factor for the regulation of gene transcription at the NMJ.

Our findings are of particular interest because GABP is an ubiquitously expressed transcription factor that has been implicated in many different processes, such as regulation of cytochrome oxidase genes (Carter and Avadhani, 1994; Sucharov et al., 1995) and induction of interleukin-2 during T-cell activation (Hoffmeyer et al., 1998). The broad range of GABP function and the fact that 
A

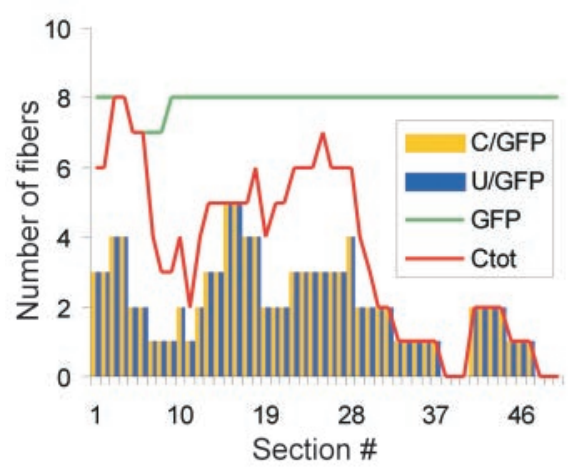

Figure 5. Distribution of utrophin and $\mathrm{AChE}$ in $\mathrm{GABP} \beta^{\mathrm{DN}}$-injected muscles. $A, B$, The distribution of utrophin was examined by immunostaining and compared with that of AChRs on cross-sections made through the injected muscle fibers. The evaluation was made as described in Figure 4. Utrophin and AChR clusters colocalized on each cross-section, throughout the injection site, in the control as well as in the GABP $\beta^{\mathrm{DN}}$ situation. $C / G F P$, GFP-positive fibers that have AChR clusters; $U / G F P$, GFP-positive fibers that have utrophin clusters; $G F P$, GFP-positive (injected) fibers; Ctot, total number of fibers having AChR clusters. $C$, The distribution of AChE was examined by choline esterase staining and compared with that of AChRs stained with alexa $\alpha$ bungarotoxin (green). Both proteins colocalized on each analyzed cross-section. Scale bar, $20 \mu \mathrm{m}$.

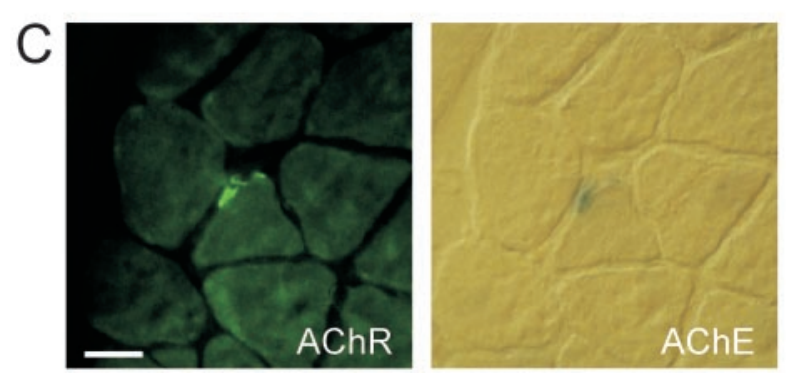

several Ets-related transcription factors have been identified, some of which have similar specificities like GABP, may hamper the chance to gain insights into GABP function at the NMJ by conventional knock-out techniques. Because we interfere locally and at a precise time point with GABP function, these pleiotropic effects do not affect our results. Thus, the system used here can be made highly specific and can be used to test the role of several other candidate genes in forming postsynaptic structures at the NMJ. In our study, we specifically interfere with GABP function because the dominant-negative GABP $\beta$ interacts with the DNA target only indirectly by its binding to the GABP $\alpha$ subunit (Brown and McKnight, 1992). This binding is highly specific and of high affinity $\left(K_{\mathrm{d}}\right.$ of $\left.7.8 \pm 0.63 \times 10^{-10} \mathrm{M}\right)$ (Suzuki et al., 1998). Therefore, the dominant-negative GABP $\beta$ will not interfere with the function of other Ets transcription factors recognizing similar sequences on the DNA.

\section{Blocking GABP function inhibits the development of the entire postsynaptic apparatus}

We show that the total number of postsynaptic-like apparatus induced by neural agrin is reduced in muscle fibers expressing a dominant-negative GABP $\beta$. Whereas $\sim 30 \%$ of the injected muscle fibers developed postsynaptic structures in the control situation, only $\sim 12 \%$ of the GABP $\beta^{\text {DN }}$-injected fibers developed postsynaptic structures (Table 1). Experimental and biological circumstances could account for the appearance of these remaining specializations on the GABP $\beta^{\text {DN }}$-expressing fibers. First, although GABP $\beta^{D N}$ blocks the induction by agrin of synaptic gene expression, a remaining basal level of transcription independent of GABP may allow the synthesis of an amount of synaptic components sufficient to form some postsynaptic specializations. Second, injury caused to the muscle fibers by the injection procedure may activate myogenic transcription factors that are known to drive the expression of synaptic genes during preinnervation stages of development. Third, the amount of GABP $\beta^{\text {DN }}$ may not be high enough to inhibit expression of synaptic genes completely. This is of particular importance at distances far from the injection site. There, the concentration of agrin may still by high because agrin is secreted from the injected muscle fiber and accumulates in the muscle cell basal lamina. In contrast, the effect of GABP $\beta^{\mathrm{DN}}$ is critically dependent on the intracellular concentration of the dominant-negative acting construct.

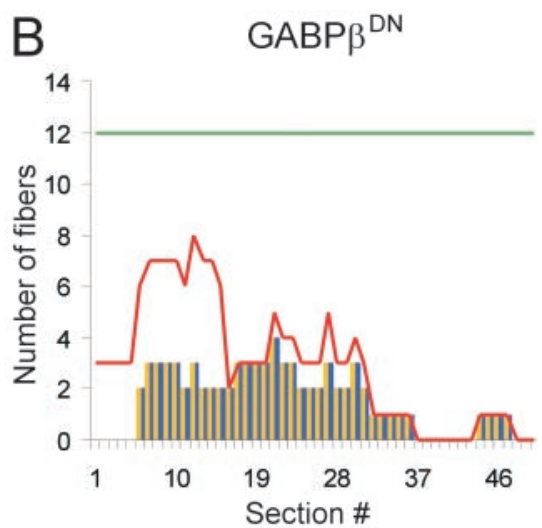

Whenever we found $\mathrm{AChR}$ clusters in $\mathrm{GABP} \beta^{\mathrm{DN}}$-expressing muscle fibers, they always included other components of the postsynaptic apparatus. Reciprocally, these other components never formed aggregates devoid of AChRs. For example, utrophin and AChE were always associated with the ectopic AChR clusters, as it is the case at normal NMJs (Fig. 5). This suggests that $\operatorname{GABP} \beta^{\mathrm{DN}}$ inhibits the formation of the entire postsynaptic apparatus without affecting the mechanism governing the assembly of postsynaptic proteins into a complex per se. There are two distinct possibilities to explain this phenomenon. First, GABP may be involved in the regulation of all genes preferentially expressed at the NMJ. We think that this possibility is rather unlikely. Second, interfering with the expression of some of the key components of the postsynaptic apparatus may preclude the development of the entire complex. This latter possibility is accredited by the profound perturbation of synaptic protein distribution observed in mice in which single components of the postsynaptic apparatus were knocked-out. For example, animals deficient of AChR $\epsilon$ subunit gene show degeneration of the entire postsynaptic apparatus because of the failure of these animals to assemble enough functional AChRs (Missias et al., 1997). Moreover, in rapsyn-deficient mice, all of the components normally concentrated in the postsynaptic membrane and cytoskeleton fail to aggregate underneath the motor nerve terminal, except the receptor tyrosine kinase MuSK (Gautam et al., 1995; Apel et al., 1997). However, in these mice, AChR subunit genes remain selectively transcribed in synaptic myonuclei. Thus, absence of rapsyn is sufficient to prevent the assembly of the entire postsynaptic complex but does not interfere with local induction of synaptic gene transcription. These experiments support the view that removal of one single component can destabilize the entire postsynaptic complex, although synthesis of other components is unaffected. To distinguish between the possibilities of GABP regulating all synaptic genes or activating the transcription of few essential components of the postsynaptic apparatus, it will be necessary to investigate the influence of GABP on the expression of the other synaptic genes at the mRNA level.

\section{Role of GABP in the maintenance of adult postsynaptic structures}

The adult postsynaptic apparatus is a very stable structure that is linked to both the extracellular basal lamina and the cytoskeleton. Moreover, in adult NMJs, AChRs have an increased half-life of 
$\sim 10$ d (Levitt et al., 1980). It will therefore be interesting to investigate whether GABP is also required for the maintenance of adult postsynaptic structures. A role of GABP in the maturation and the maintenance of the postsynaptic apparatus is supported by the fact that single base pair mutations in the N-box of the AChRe subunit promoter are associated with a particular form of congenital myasthenic syndromes (Nichols et al., 1999; Ohno et al., 1999). Thus, failure to activate synaptic transcription of the AChR $\epsilon$ subunit may cause a decrease of AChR density and a subsequent impairment of neuromuscular transmission. In line with this, in the muscle biopsy of one patient with a 1 bp mutation in the N-box, the number of endplate AChRs quantified by ${ }^{125} \mathrm{I}-\alpha$-bungarotoxin binding is reduced (Nichols et al., 1999). We are currently investigating whether this mutation in the $\epsilon$ promoter affects its responsiveness to neural agrin in innervated muscle fibers.

\section{REFERENCES}

Apel ED, Glass DJ, Moscoso LM, Yancopoulos GD, Sanes JR (1997) Rapsyn is required for MuSK signalling and recruits synaptic components to a MuSK-containing scaffold. Neuron 18:623-635.

Batchelor AH, Piper DE, de la Brousse FC, McKnight SL, Wolberger C (1998) The structure of GABPalpha/beta: an ETS domain- ankyrin repeat heterodimer bound to DNA. Science 279:1037-1041.

Bowen DC, Park JS, Bodine S, Stark JL, Valenzuela DM, Stitt TN, Yancopoulos GD, Lindsay RM, Glass DJ, DiStefano PS (1998) Localization and regulation of MuSK at the neuromuscular junction. Dev Biol 199:309-319.

Brenner HR, Witzemann V, Sakmann B (1990) Imprinting of acetylcholine receptor messenger RNA accumulation in mammalian neuromuscular synapses. Nature 344:544-547.

Brown TA, McKnight SL (1992) Specificities of protein-protein and protein-DNA interaction of GABP alpha and two newly defined ets-related proteins. Genes Dev 6:2502-2512.

Buonanno A, Apone L, Morasso MI, Beers R, Brenner HR, Eftimie R (1992) The MyoD family of myogenic factors is regulated by electrical activity: isolation and characterization of a mouse Myf-5 cDNA. Nucleic Acids Res 20:539-544.

Carter RS, Avadhani NG (1994) Cooperative binding of GA-binding protein transcription factors to duplicated transcription initiation region repeats of the cytochrome c oxidase subunit IV gene. J Biol Chem 269:4381-4387.

Chan RY, Boudreau-Lariviere C, Angus LM, Mankal FA, Jasmin BJ (1999) An intronic enhancer containing an N-box motif is required for synapse- and tissue-specific expression of the acetylcholinesterase gene in skeletal muscle fibers. Proc Natl Acad Sci USA 96:4627-4632.

Chu GC, Moscoso LM, Sliwkowski MX, Merlie JP (1995) Regulation of the acetylcholine receptor $\epsilon$-subunit gene by recombinant ARIA: an in vitro model for transynaptic gene regulation. Neuron 14:329-339.

Cohen I, Rimer M, Lomo T, McMahan UJ (1997) Agrin-induced postsynaptic apparatus in skeletal muscle fibers in vivo. Mol Cell Neurosci 9:237-253.

DeChiara TM, Bowen DC, Valenzuela DM, Simmons MV, Poueymirou WT, Thomas S, Kinetz E, Compton DL, Rojas E, Park JS, Smith C, DiStefano PS, Glass DJ, Burden SJ, Yancopoulos GD (1996) The receptor tyrosine kinase MuSK is required for neuromuscular junction formation in vivo. Cell 85:501-512.

Denzer AJ, Gesemann M, Schumacher B, Ruegg MA (1995) An aminoterminal extension is required for the secretion of chick agrin and its binding to extracellular matrix. J Cell Biol 131:1547-1560.

Duclert A, Changeux JP (1995) Acetylcholine receptor gene expression at the developing neuromuscular junction. Physiol Rev 75:339-368.

Duclert A, Savatier N, Changeux JP (1993) Ân 83-nucleotide promoter of the acetylcholine receptor epsilon-subunit gene confers preferential synaptic expression in mouse muscle. Proc Natl Acad Sci USA 90:3043-3047.

Duclert A, Savatier N, Schaeffer L, Changeux JP (1996) Identification of an element crucial for the sub-synaptic expression of the acetylcholine receptor epsilon-subunit gene. J Biol Chem 271:17433-17438.

Edmondson DG, Olson EN (1993) Helix-loop-helix proteins as regulators of muscle-specific transcription. J Biol Chem 268:755-758.

Eftimie R, Brenner HR, Buonanno A (1991) Myogenin and MyoD join a family of skeletal muscle genes regulated by electrical activity. Proc Nat Acad Sci USA 88:1349-1353.

Evan GI, Lewis GK, Ramsay G, Bishop JM (1985) Isolation of monoclonal antibodies specific for human c-myc proto-oncogene product. Mol Cell Biol 5:3610-3616.

Fischbach GD, Rosen KM (1997) ARIA: a neuromuscular junction neuregulin. Annu Rev Neurosci 20:429-458.

Fromm L, Burden SJ (1998) Synapse-specific and neuregulin-induced transcription require an ets site that binds GABPalpha/GABPbeta. Genes Dev 12:3074-3083.

Gautam M, Noakes PG, Mudd J, Nichol M, Chu GC, Sanes JR, Merlie JP (1995) Failure of postsynaptic specialization to develop at neuromuscular junctions of rapsyn-deficient mice. Nature 377:232-236.
Gautam M, Noakes PG, Moscoso L, Rupp F, Scheller RH, Merlie JP, Sanes JR (1996) Defective neuromuscular synaptogenesis in agrin-deficient mutant mice. Cell 85:525-535.

Glass DJ, Bowen DC, Stitt TN, Radziejewski C, Bruno J, Ryan TE, Gies DR, Shah S, Mattsson K, Burden SJ, DiStefano PS, Valenzuela DM, DeChiara TM, Yancopoulos GD (1996) Agrin acts via a MuSK receptor complex. Cell 85:513-523.

Gluzman Y (1981) SV40-transformed simian cells support the replication of early SV40 mutants. Cell 23:175-182.

Goldman D, Staple J (1989) Spatial and temporal expression of acetylcholine receptor RNAs in innervated and denervated rat soleus muscle. Neuron 3:219-228.

Grady RM, Merlie JP, Sanes JR (1997) Subtle neuromuscular defects in utrophin-deficient mice. J Cell Biol 136:871-882.

Gramolini AO, Angus LM, Schaeffer L, Burton EA, Tinsley JM, Davies KE, Changeux JP, Jasmin BJ (1999) Induction of utrophin gene expression by heregulin in skeletal muscle cells: role of the N-box motif and GA binding protein. Proc Natl Acad Sci USA 96:3223-3227.

Hoffmeyer A, Avots A, Flory E, Weber CK, Serfling E, Rapp UR (1998) The GABP-responsive element of the interleukin-2 enhancer is regulated by JNK/SAPK-activating pathways in T lymphocytes. J Biol Chem 273:10112-10119.

Huang CF, Tong J, Schmidt J (1992) Protein kinase C couples membrane excitation to acetylcholine receptor gene inactivation in chick skeletal muscle. Neuron 9:671-678.

Huang CF, Neville CM, Schmidt J (1993) Control of myogenic factor genes by the membrane depolarization/protein kinase $\mathrm{C}$ cascade in chick skeletal muscle. FEBS Lett 319:21-25.

Jaynes JB, Chamberlain JS, Buskin JN, Johnson JE, Hauschka SD (1986) Transcriptional regulation of the muscle creatine kinase gene and regulated expression in transfected mouse myoblasts. Mol Cell Biol 6:2855-2864.

Jones G, Herczeg A, Ruegg MA, Lichtsteiner M, Kröger S, Brenner HR (1996) Substrate-bound agrin induces expression of acetylcholine receptor $\epsilon$-subunit gene in cultured mammalian muscle cells. Proc Natl Acad Sci USA 93:5985-5990.

Jones G, Meier T, Lichtsteiner M, Witzemann V, Sakmann B, Brenner HR (1997) Induction by agrin of ectopic and functional postsynaptic-like membrane in innervated muscle. Proc Natl Acad Sci USA 94:2654-2659.

Jones G, Moore C, Hashemolhosseini S, Brenner HR (1999) Constitutively active MuSK is clustered in the absence of agrin and induces ectopic postsynaptic-like membranes in skeletal muscle fibers. J Neurosci 19:3376-3383.

Khurana TS, Rosmarin AG, Shang J, Krag TO, Das S, Gammeltoft S (1999) Activation of utrophin promoter by heregulin via the ets-related transcription factor complex GA-binding protein alpha/beta. Mol Biol Cell 10:2075-2086.

Koike S, Schaeffer L, Changeux JP (1995) Identification of a DNA element determining synaptic expression of the mouse acetylcholine receptor ë-subunit gene. Proc Natl Acad Sci USA 92:10624-10628.

LaMarco K, Thompson CC, Byers BP, Walton EM, McKnight SL (1991) Identification of Ets- and notch-related subunits in GA binding protein. Science 253:789-792.

Lanford RE, White RG, Dunham RG, Kanda P (1988) Effect of basic and nonbasic amino acid substitutions on transport induced by simian virus 40 T-antigen synthetic peptide nuclear transport signals. Mol Cell Biol 8:2722-2729.

Levitt TA, Loring RH, Salpeter MM (1980) Neuronal control of acetylcholine receptor turnover rate at a vertebrate neuromuscular junction. Science 210:550-551.

Meier T, Hauser DM, Chiquet M, Landmann L, Ruegg MA, Brenner HR (1997) Neural agrin induces ectopic postsynaptic specializations in innervated muscle fibers. J Neurosci 17:6534-6544.

Meier T, Marangi PA, Moll J, Hauser DM, Brenner HR, Ruegg MA (1998a) A minigene of neural agrin encoding the laminin-binding and acetylcholine receptor-aggregating domains is sufficient to induce postsynaptic differentiation in muscle fibres. Eur $\mathrm{J}$ Neurosci 10:3141-3152.

Meier T, Masciulli F, Moore C, Schoumacher F, Eppenberger U, Denzer AJ, Jones G, Brenner HR (1998b) Agrin can mediate acetylcholine receptor gene expression in muscle by aggregation of muscle-derived neuregulins. J Cell Biol 141:715-726.

Mendelzon D, Changeux JP, Nghiem HO (1994) Phosphorylation of myogenin in chick myotubes: regulation by electrical activity and by protein kinase C. Implications for acetylcholine receptor gene expression. Biochemistry 33:2568-2575.

Merlie JP, Mudd J, Cheng TC, Olson EN (1994) Myogenin and acetylcholine receptor alpha gene promoters mediate transcriptional regulation in response to motor innervation. J Biol Chem 269:2461-2467.

Missias AC, Mudd J, Cunningham JM, Steinbach JH, Merlie JP, Sanes JR (1997) Deficient development and maintenance of postsynaptic specializations in mutant mice lacking an "adult" acetylcholine receptor subunit. Development 124:5075-5086.

Moscoso LM, Merlie JP, Sanes JR (1995) N-CAM, 43K-rapsyn, and S-laminin mRNAs are concentrated at synaptic sites in muscle fibers. Mol Cell Neurosci 6:80-89. 
Neville CM, Schmidt J (1992) Expression of myogenic factors in skeletal muscle and electric organ of Torpedo californica. FEBS Lett 305:23-26.

Nichols P, Croxen R, Vincent A, Rutter R, Hutchinson M, Newsom-Davis J, Beeson D (1999) Mutation of the acetylcholine receptor epsilonsubunit promoter in congenital myasthenic syndrome. Ann Neurol 45:439-443

Ohno K, Anlar B, Engel AG (1999) Congenital myasthenic syndrome caused by a mutation in the Ets-binding site of the promoter region of the acetylcholine receptor epsilon subunit gene. Neuromuscul Disord 9:131-135.

Patton BL, Miner JH, Chiu AY, Sanes JR (1997) Distribution and function of laminins in the neuromuscular system of developing, adult, and mutant mice. J Cell Biol 139:1507-1521.

Pestronk A, Drachman DB (1978) A new stain for quantitative measurement of sprouting at neuromuscular junctions. Muscle Nerve 1:70-74

Rimer M, Mathiesen I, Lomo T, McMahan UJ (1997) $\gamma$-AChR/ $\epsilon$-AChR switch at agrin-induced postsynaptic-like apparatus in skeletal muscle. Mol Cell Neurosci 9:254-263.

Rimer M, Cohen I, Lomo T, Burden SJ, McMahan UJ (1998) Neuregulins and erbB receptors at neuromuscular junctions and at agrin- induced postsynaptic-like apparatus in skeletal muscle. Mol Cell Neurosci 12:1-15.

Ruegg MA, Bixby JL (1998) Agrin orchestrates synaptic differentiation at the vertebrate neuromuscular junction. Trends Neurosci 21:22-27.

Sandrock Jr AW, Dryer SE, Rosen KM, Gozani SN, Kramer R, Theill LE, Fischbach GD (1997) Maintenance of acetylcholine receptor number by neuregulins at the neuromuscular junction in vivo. Science 276:599-603.

Sanes JR, Lichtman JW (1999) Development of the vertebrate neuromuscular junction. Annu Rev Neurosci 22:389-442.

Sapru MK, Florance SK, Kirk C, Goldman D (1998) Identification of a neuregulin and protein-tyrosine phosphatase response element in the nicotinic acetylcholine receptor epsilon subunit gene: regulatory role of an Rts transcription factor. Proc Natl Acad Sci USA 95:1289-1294.

Sawa C, Goto M, Suzuki F, Watanabe H, Sawada J, Handa H (1996) Functional domains of transcription factor hGABP beta1/E4TF1-53 required for nuclear localization and transcription activation. Nucleic Acids Res 24:4954-4961.

Schaeffer L, Duclert N, Huchet-Dymanus M, Changeux JP (1998) Implication of a multisubunit Ets-related transcription factor in synaptic expression of the nicotinic acetylcholine receptor. EMBO J 17:3078-3090.

Si J, Mei L (1999) ERK MAP kinase activation is required for acetylcholine receptor inducing activity-induced increase in all five acetylcholine receptor subunit mRNAs as well as synapse-specific expression of acetylcholine receptor varepsilon-transgene. Brain Res Mol Brain Res 67:18-27.

Sucharov C, Basu A, Carter RS, Avadhani NG (1995) A novel transcriptional initiator activity of the GABP factor binding ets sequence repeat from the murine cytochrome c oxidase Vb gene. Gene Expr 5:93-111.

Suzuki F, Goto M, Sawa C, Ito S, Watanabe H, Sawada J, Handa H (1998) Functional interactions of transcription factor human GA-binding protein subunits. J Biol Chem 273:29302-29308.

Thompson CC, Brown TA, McKnight SL (1991) Convergence of Ets- and notch-related structural motifs in a heteromeric DNA binding complex. Science 253:762-768.

Wallace BG (1988) Regulation of agrin-induced acetylcholine receptor aggregation by $\mathrm{Ca}++$ and phorbol ester. J Cell Biol 107:267-278.

Weintraub H (1993) The MyoD family and myogenesis: redundancy, networks, and thresholds. Cell 75:1241-1244.

Witzemann V, Sakmann B (1991) Differential regulation of MyoD and myogenin mRNA levels by nerve induced muscle activity. FEBS Lett 282:259-264. 